\title{
A Misconception Analysis of Biology Students of Universitas Negeri Padang in the Microbiology Subject Using Certainly of Response Index (CRI)
}

\author{
Ulima Yafi Ilmisa ${ }^{1 *}$ Dwi Hilda Putri ${ }^{1}$ \\ ${ }^{1}$ Dept. of Biology, Faculty of Mathematics and Science (FMIPA), Universitas Negeri Padang, Padang, Indonesia \\ ${ }^{*}$ Corresponding author. Email: ulimabio13@gmail.com
}

\begin{abstract}
This study aims at determining students' misconceptions in the microbiology subject. The object of this study was the biology students at the Faculty of Mathematics and Natural Sciences, Universitas negeri Padang (UNP) who took the microbiology subject in 2018/2019 school year. The number of students was 142 students. This study was a descriptive research. This study used diagnostic tests in the form of multiple choice questions and the Certainly of Response Index (CRI) technique. The CRI technique was an index of student confidence in answers that are considered correct. CRI diagnostic data analysis results showed that as many as $36.75 \%$ of students understood the concept, $35.43 \%$ did not understand the concept, and $27.82 \%$ experienced misconceptions. Student misconceptions were influenced by the understanding that was influenced by the experiences of the students that they have in their daily lives and the textbooks they use. Textbooks used in learning have not linked problems in daily life that support understanding of student concepts. The textbook used was an old book, so there was no novelty of knowledge.
\end{abstract}

Keywords: misconception, microbiology, Certainly of Response Index (CRI)

\section{INTRODUCTION}

Students already have preconceptions or ideas obtained through experience and ideas that are formed when interacting with their environment before learning takes place in class[1,2]. If students' preconceptions are not appropriate with scientific concepts, they are called concept misconceptions. Understanding of concepts that are not in accordance with scientific explanations is defined as misconceptions[3,4].

Educational research has documented many biological misconceptions, such as in evolution, respiration, photosynthesis, molecular genetics substances, host symbiotic associations with pathogens [5-10]. Misconceptions are difficult to overcome, because if students experience a misconception on one of the basic concepts, then the possibility of the emergence of misconceptions on complex concepts is higher [11]. Misconceptions result in inhibition of knowledge acceptance and assimilation, thus affecting student learning outcomes. Misconception is the main problem and focus in the development of microbiology curriculum[12]. Misconception is caused by preconceptions, associative thinking, humanistic thinking, wrong reasoning, wrong intuition, stages of student cognitive development, students' abilities and interests in learning, teachers, textbooks, and methods study [13].

Microbiology is a branch of biology, which studies microscopic life-sized creatures. The object of microbiological studies is prokaryotes and viruses. Microbiology courses are a requirement for taking advanced courses such as biotechnology and applied microbiology courses at UNP. Students' understanding of microbiology courses affects the understanding of material in other subjects and making students' final assignments, when conducting research related to microbiology. Therefore, the misconception in this subject must be resolved quickly and accurately. Efforts in overcoming and preventing misconceptions can be done by identifying concepts that are experiencing misconceptions and analyzing the causative factors[12,14].

The urgency of the problem of misconception drives researchers to carry out this research. This study aims to analyze student misconceptions in microbiology courses. The analysis in this study includes material that experiences misconceptions and causes of the emergence of misconceptions.

\section{MATERIALS AND METHODS}

\subsection{Identification of misconceptions}

Identification of student misconceptions in the microbiology subject used multiple choice questions and the Certainly of Response Index (CRI)[15]. Students as objects in this study were the students who took the Microbiology Subject in 2018/2019 academic year. The 
material was tested on multiple choice questions appropriate with learning outcomes after the midterm exams listed in the syllabus.

MCQs were 50 and were tested at the end of the semester exams in microbiology. The Certainly of Response Index (CRI) technique[16] used has been modified, but the principles of the CRI remain applied. The CRI technique was characterized by a scale of confidence in answering questions[17]. The scale used in this study was 1-3 (Table $1)$.

Table 1.The scale of confidence level in answering questions based on the Certainly of Response Index technique.

\begin{tabular}{|r|l|}
\hline $\begin{array}{r}\text { I } \\
\text { ndex }\end{array}$ & \multicolumn{1}{c|}{ Criteria } \\
\hline 3 & $\begin{array}{l}\text { Sure } \\
\text { (if level of confidence of the truth the answer } \\
\text { is 76-100\%) }\end{array}$ \\
\hline 2 & $\begin{array}{l}\text { Doubtful } \\
\text { (if level of confidence of the truth the answer } \\
\text { is 36-75\%) }\end{array}$ \\
\hline 1 & $\begin{array}{l}\text { Not Sure } \\
\text { (if level of confidence of the truth the answer } \\
\text { is 0-35\%) }\end{array}$ \\
\hline
\end{tabular}

Criteria in the Certainly of Response Index technique for identifying misconceptions used modification. The evaluation criteria using the CRI modification technique[18] have been modified according to the research needs. CRI technique evaluation criteria can be seen in Table 2.

Table 2. The assessment criteria with the Certainly of Response Index Technique.

\begin{tabular}{|c|l|l|}
\hline $\begin{array}{c}\text { Answer } \\
\text { Category }\end{array}$ & $\begin{array}{c}\text { CRI } \\
\text { Criteria }\end{array}$ & \multicolumn{1}{c|}{ Category } \\
\hline \multirow{2}{*}{$\begin{array}{c}\text { Correct } \\
\text { Answer }\end{array}$} & Not Sure & Did not understand the concept \\
\cline { 2 - 3 } & Doubtful & Did not understand the concept \\
\cline { 2 - 3 } & Sure & Understood the concept \\
\hline \multirow{2}{*}{$\begin{array}{c}\text { Wrong } \\
\text { Answer }\end{array}$} & Not Sure & Did not understand the concept \\
\cline { 2 - 3 } & Doubtful & Did not understand the concept \\
\cline { 2 - 3 } & Sure & Misconception \\
\hline
\end{tabular}

\subsection{Interview}

Misconceptions occurred due to several factors[13]. The factors causing misconceptions in this study were analyzed through the results of interviews conducted with lecturers and students. The samples were selected by using a purposive sampling technique[19]. There were 2 lecturers interviewed and 4 students interviewed.

\subsection{Textbook Analysis}

Microbiology textbooks used by the students were analyzed according to the learning needs and syllabus used[13]. The textbook content was analyzed based on the results of the student's learning needs interview. The scope of the textbook material was analyzed based on the provision of learning outcomes in the microbiology syllabus.

\section{RESULT AND DISCUSSION}

The percentage of the students' understanding of concepts in the Microbiology Subject can be divided into three categories, namely understanding concepts, not understanding concepts and misconceptions[18]. The results of the percentage of the students' understanding of the concept can be seen in Figure 1.

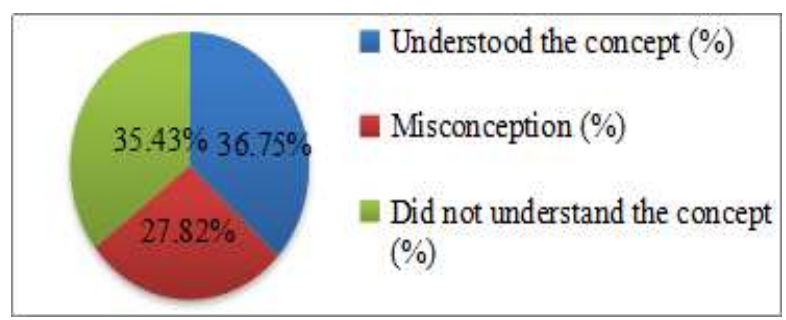

Figure 1. The percentage of students' understanding concepts in microbiology materials

Misconceptions analyzed in the Microbiology Subject included microbial physiology, microbial genetics, symbiotic associations, soil microbiology, food microbiology, water microbiology, and clinical microbiology. The details of the percentage of the students' understanding of concepts in the materials can be seen in Figure 2.

Based on the interview results it was known that the factors that encouraged the students' interest in studying microbiology were the existence of contextual discussions and the application of microbiology in life. Based on the analysis results, the textbook used was not appropriate with the syllabus. The presentation of the material was not equipped with the application of concepts in daily life, and there is no renewal of knowledge. The incompatibility of textbooks with syllabus and interest in learning, resulting in students tend to use supporting references. The references used tend to be sourced from blogs rather than journals and other scientific references. 


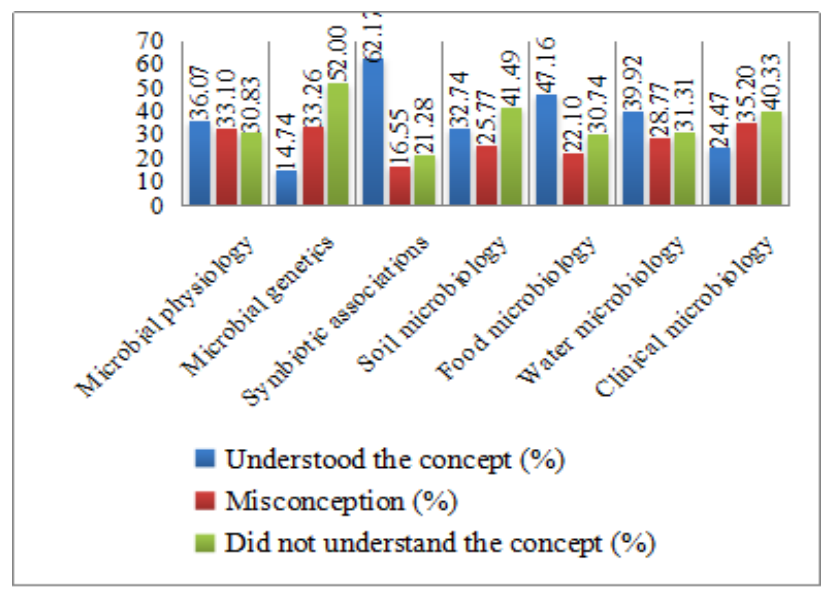

Figure 2. The percentage of the students' understanding concepts in microbiology materials

The students have misconceptions with a percentage of $28 \%$ (Figure 1). Misconceptions experienced by the students occurred in all material tested on multiple choice questions. Errors in analyzing problems can trigger student misconceptions[13]. Some examples of misconceptions experienced by students can be seen in Table 3 .

In the learning process lecturers have used several methods to overcome student misconceptions. The students have been directed to understand the concepts learned correctly. However, the students are still constrained in understanding the concept. That is because it is difficult to change because many misconceptions occur starting from elementary school students to university students and are influenced by the experience they have[20].

Factors causing misconceptions of the students are the use of textbooks. Misconceptions originating from textbooks are caused by language that is difficult to understand and has incorrect explanations. The presentation of pictures, graphs, tables, and other forms can lead to misconceptions, due to students' selflimitations in understanding them[13]. The microbiology textbook used at UNP is not relevant to interests, learning needs, and leaning outcomes in the learning process. The textbook used is an old book. The book has no novelty and has not been optimal in the application of concepts learned in life.

Table 3. Misconceptions on microbiology materials

\begin{tabular}{|c|c|}
\hline $\begin{array}{l}\text { Materia } \\
\text { ls }\end{array}$ & Misconceptions \\
\hline \multirow[t]{3}{*}{$\begin{array}{l}\text { Microbi } \\
\text { al Physiology }\end{array}$} & $\begin{array}{l}1 . \quad \text { Utilization of applied } \\
\text { technology is a basic principle of } \\
\text { conventional biotechnology }\end{array}$ \\
\hline & $\begin{array}{l}2 . \quad \text { Fermentation can } \\
\text { only occur under anaerobic } \\
\text { conditions }\end{array}$ \\
\hline & 3. Different types of \\
\hline
\end{tabular}

\begin{tabular}{|c|c|}
\hline & $\begin{array}{l}\text { microbes will only secrete the } \\
\text { same enzyme for the same material }\end{array}$ \\
\hline $\begin{array}{l}\text { Microbi } \\
\text { al Genetics }\end{array}$ & $\begin{array}{c}1 . \quad \text { Plasmids are linear } \\
2 . \quad \text { Bacterial conjugation } \\
\text { cannot lead to antibiotic resistance } \\
3 . \quad \text { Recombination of } \\
\text { genetic material can be mediated } \\
\text { by all types of viruses }\end{array}$ \\
\hline $\begin{array}{l}\text { Symbiot } \\
\text { ic } \\
\text { Association }\end{array}$ & $\begin{array}{c}\text { 1. Pathogenicity is a } \\
\text { mechanism for developing disease }\end{array}$ \\
\hline $\begin{array}{c}\text { Soil } \\
\text { microbiology }\end{array}$ & $\begin{array}{l}1 . \text { In soils there are } \\
\text { many types of microorganisms, } \\
\text { because the temperature and } \mathrm{pH} \text { of } \\
\text { the soil are ideal for growth. } \\
2 . \quad \text { Bacteria in soil } \\
\text { produce spores to breed } \\
3 \text {. The benefits of } \\
\text { mycorrhiza for plants are for the } \\
\text { growth of root nodules }\end{array}$ \\
\hline $\begin{array}{c}\text { Food } \\
\text { microbiology }\end{array}$ & $\begin{array}{l}1 . \\
\text { Terms of microbes } \\
\text { as food is easy to mutate } \\
2 . \\
\text { Genetically Modified Organism } \\
\text { (GMO) in food is aimed at } \\
\text { informing the presence of toxic } \\
\text { contents that cause gene mutations. } \\
3 \text {. The role of adding } \\
\text { microbes in food is to reduce the } \\
\text { number of probiotic microbes }\end{array}$ \\
\hline $\begin{array}{c}\text { Water } \\
\text { microbiology }\end{array}$ & $\begin{array}{l}\text { 1. Water is an ideal } \\
\text { place to live for microbes } \\
2 . \\
\text { Biological The lower the } \\
\text { (BOD) value the lower the water } \\
\text { quality } \\
3 . \\
\text { coliform test is definitely fit for } \\
\text { consumption }\end{array}$ \\
\hline $\begin{array}{r}\text { Clinical } \\
\text { microbiology }\end{array}$ & $\begin{array}{l}\text { 1. Proper handling of } \\
\text { bacterial infections using vaccines } \\
2 . \quad \text { HIV can infect all } \\
\text { types of cells } \\
3 . \quad \text { Viruses cannot } \\
\text { undergo genetic mutations } \\
4 . \quad \text { Rickettsia typhi } \\
\text { Bacteria that causes typhus is } \\
\text { transmitted through mosquitoesk }\end{array}$ \\
\hline
\end{tabular}




\section{CONCLUSION}

UNP biology students in the microbiology subject in 2018/2019 academic year experienced a misconception of $27.82 \%$. The students who understood the concept were $36.75 \%$, while $35.43 \%$ of the students did not understand the concept. The main factor in the students' misconceptions was the use of textbooks that were not relevant to their interests, learning needs, and learning outcomes. For the future studies, researchers will focus on efforts to overcome the misconceptions that occur in UNP biology students on the Microbiology Subject.

\section{REFERENCES}

[1] Longfield J 2009 Discrepant teaching events: using an inquiry stance to address students' misconceptions. International Journal of Teaching and Learning in Higher Education 21(2):265-271

[2] Tayubi YR 2005 Identifikasi miskonsepsi pada konsep-konsep fisika menggunakan Certainty of Response Index (CRI). Mimbar Pendidikan No.3/XXIV/2005:4-9

[3] Ross P, Tronson D, and Raymond JR 2006, Modeling photosynthesis to increase conceptual understanding. Journal of Biological Education 40(2):84-88

[4] Syahrul DA, Setyarsih W 2015 Identifikasi miskonsepsi dan penyebab miskonsepsi siswa dengan Three-Tier Diagnostic Test pada materi dinamika rotasi. Jurnal Inovasi Pendidikan Fisika (JIPF) 3(03):67-70

[5] Lewis J, Leach J, Wood-Robinson C 2000 What's in a cell? - Young people's understanding of the genetic relationship between cells, within an individual. Journal Biol Educ 34:129-132

[6] Marbach-Ad G, McAdams KC, Benson S, Briken V, Chathcart L, Chase M, El-sayed NM, Frauwirth K, Fredericksem B, Joseph SW 2010 A model for using a concept inventory as a tool for student's assessment anf faculty professional development. CBE Life Sci Educ 9:408-416

[7] Wright LK, Fisk JN, Newman DL. 2014 DNA $\rightarrow$ RNA: what do student think the arrow means? CBE Life Sci Educ 13:338-348

[8] Venville G, Gribble SJ, Donovan J 2005 An exploration of young children's understanding of genetics concepts from ontological and epistemological perspective. Sci Educ 89:614-633
[9] Mustaqim TA, Zulfiani, Herlanti Y 2014 Identifikasi miskonsepsi siswa dengan menggunakan metode Certainty of Response Index (CRI) pada konsep fotosintesis dan respirasi tumbuhan. Edusains 4(02):146-152

[10] Murni D 2013 Identifikasi miskonsepsi mahasiswa pada konsep substansi genetika menggunakan Certainty of Response Index (CRI). Prosisding Semirata FMIPA Universitas Lampung 205211

[11] McDonald K, Gomes J 2013 Evaluating student preparedness and conceptual change in introductory biology students studying gene expression. J Transform Leaders Policy Stud 3:21

[12] Briggs AG, Lee EH, Robert EB, John B, Rachel EA, Horack, D.Sue KA, Ann H, McDonald, Todd PP, Ann CS, Ann MS, Sunny BY, Timotty DP 2017 Concept inventory development revals common student misconceptions about microbiology. Jounal of Microbiology and Biology Education 18(3)

[13] Suparno, Paul 2013 Miskonsepsi dan perubahan konsep dalam pendidikan fisika cetakan kedua. Jakarta: PT Grasindo

[14] Salirawati D 2011 Pengembangan instrumen pendeteksi miskonsepsi kesetimbangan kimia pada peserta didik SMA. Jurnal Penelitian dan Evaluasi Pendidikan 15(2):232- 249

[15] Yusuf F 2008 Evaluasi program dan instrumen evaluasi untuk program pendidikan dan penelitian.

Jakarta: Rineka Cipta

[16] Hasan S, Bagayoko D, Kelly EL 1999 Misconceptions and the Certainly of Respons Index (CRI). Phys Educ 34(5):294-297

[17] Ramadhan M, Sunardi, Kurniati D 2017 Analisis miskonsepsi siswa dalam menyelesaikan soal matematika berstandar PISA dengan menggunakan Certainly of Respons Index 8:145-153

[18] Hakim et al. 2012 Student concept understanding of natural product chemistry in primary and secondary metabolis using the data collections technique of modified CRI. International Online Journal of Education Science 4(3)

[19] Sugiyono 2011 Metode penelitian kuantitatif, kualitatif dan R\&D. Bandung: Alfabeta

[20] Hidayati I 2013 Analisis miskonsepsi guru dan buku teks biologi kelas XI SMAN pada materi sistem saraf di Kabupaten Nagan Raya. Tesis Banda Aceh: Universitas Syiah Kuala 